\title{
Edutainment jako przestrzeń edukacji nieformalnej. Edukacyjny potencjał programów telewizyjnych w świetle analizy serialu „Głęboka woda” i wypowiedzi jego odbiorców
}

\begin{abstract}
Television is now recognized as a key source of knowledge about the social and cultural reality. TV series is one of the genre with special role on this field. It's norm-creating properties have been spotted already in the 70's and used to construct the first, based on narrative, edutainment programs. The article is focused on the series about social workers "Into deep water". This TV show was creating by Ministry of Labor and Social Policy and it's first example of education series in Poland. The author analyzes pop culture text based on education-entertainment strategy and educational potential of series. The empirical basis for article are written expression and qualitative research interviews. The aim of the research was verification the educational extent of the "Into deep water" and what it is. The main conclusion that results from the analysis is that the show is more PR tool than educational.
\end{abstract}

\section{Keywords:}

edutainment, TV series, media, welfare

1 Joanna Anioł, Zakład Edukacji Dorosłych i Studiów Kulturowych, Instytut Pedagogiki, Wydział Nauk Historycznych i Pedagogicznych, Uniwersytet Wrocławski, Polska, joanna.aniol@ gmail.com. 


\section{EDUTAINMENT JAKO ŹRÓDŁO ZMIANY SPOŁECZNEJ}

Wraz z intensywnym rozwojem mediów i stopniowym zwiększaniem się ich znaczenia w codziennym życiu, wiele aspektów funkcjonowania społeczeństw modernistycznych i postmodernistycznych uległo nieodwracalnym zmianom. Rozwój prasy, radia, telewizji, a następnie Internetu, spowodował przełom w zakresie uczestnictwa w życiu publicznym i politycznym, dostępności rozrywki, źródeł i jakości autorytetów, powszechności wiedzy i informacji, a także oddziaływań edukacyjnych i socjalizacyjnych. Rodzina, Kościół i szkoła stopniowo zastępowane były przez poradniki, komiksy, słuchowiska radiowe, filmy i seriale telewizyjne jako podłoża wartości moralnych i duchowych, norm społecznych oraz wiedzy o życiu i świecie (Jakubowski, 2014).

„Moc” środków masowego przekazu jako potencjalnego czynnika uruchamiającego proces przeobrażeń w sferze postaw, przekonań i zachowań została po raz pierwszy wykorzystana na szeroką skalę przez Miguela Sabido w latach siedemdziesiątych. Sabido, będąc pracownikiem olbrzymiej korporacji telewizyjnej Televisa, mającej wpływ na zawartość ramówki w większości krajów Ameryki Łacińskiej, dostrzegł, że niezwykle popularne i łatwo dostępne w ówczesnych czasach opery mydlane mogą stać się impulsem do zmian społecznych. Pracując początkowo jako producent teatralny, został wkrótce scenarzystą i producentem m.in. takich widowisk telewizyjnych, jak: „Vamos Juntos”, „Acompáñame” i „Ven Conmigo”, promujących świadome planowanie rodziny, edukację dorosłych i odpowiedzialne rodzicielstwo. Współcześnie uznawany jest za twórcę paradygmatu edurozrywki (Singhal, Rogers, 2011).

Od momentu powstania pierwszych programów edurozrywkowych, paradygmat ten ulegał dogłębnym przemianom. Zmieniła się zarówno treść przekazów edukacyjnych (od promowania nauki czytania i pisania wśród dorosłych po odpowiedzialne korzystanie z zasobów Ziemi i rozwiązywania kluczowych, światowych problemów), jak i ich forma (rozszerzenie środków przekazu na muzykę, komiksy, gry stosowane, aplikacje i opowieści transmedialne). Współcześnie edutainment definiowany jest jako „teoretycznie ugruntowana strategia komunikacyjna oparta na intencjonalnym wbudowywaniu kwestii społecznych i edukacyjnych w proces tworzenia, produkcji, przetwarzania i rozpowszechniania programów rozrywkowych, w celu osiągnięcia pożądanych zmian indywidualnych, wspólnotowych, instytucjonalnych i społecznych pośród populacji użytkowników przeznaczonych do tego mediów" (Singhal, 2013, s. 3).

Idea edutainmentu zasadza się na kilku teoriach. Najważniejszą z nich stanowi bez wątpienia społeczno-poznawcza koncepcja uczenia się z mediów masowych 
Alberta Bandury. Kluczowe tezy wspomnianej idei wywodzą się ze wcześniejszych, najsłynniejszych prac badacza poświęconych uczeniu się społecznemu. Jedną z bazowych kategorii jest modelowanie społeczne, czyli przyswajanie sobie sposobów realizacji nowych zachowań na podstawie obserwacji postępowania modela (Ptaszek, 2013). Inne ważne pojęcie to doświadczenie zastępcze. Według Doroty Kubickiej (2007), stanowi ono klucz do wyjaśnienia sposobów oddziaływania mediów na jednostki, ze względu na fakt, że dzięki mediom właśnie do „globalnego obiegu” trafiają określone sposoby rozwiązywania problemów, schematy myślowe i aksjomaty moralne. Dodatkowo, „w sposób zastępczy można uczyć się również idei, przekonań, wartości, stylów działania i myślenia, motywów, reakcji emocjonalnych i standardów samooceny” (s. 55).

Inne koncepcje, które wykorzystywane są przez twórców programów education-entertainment, to m.in. transteoretyczny model zmiany, teoria wyrozumowanego zachowania, E-ELM (extended elaboration likelihood model), agenda setting i in. (Sood, Menard, Witte, 2010).

Możliwości, jakie stwarza uczenie się dzięki mediom, są wykorzystywane w programach edurozrywkowych, które zazwyczaj docelowo mają przyczynić się do zmian w sferze postaw, zachowań i przekonań. Nie chodzi zatem o „proste” przekazanie wiedzy „opakowanej rozrywką” - edutainment, zgodnie z założeniami swoich twórców, jest narzędziem wnikającym w strukturę światopoglądu i filozofii życiowej odbiorców i kształtuje u nich pożądane wzorce behawioralne (np. przestrzeganie praw kobiet, stosowanie antykoncepcji, uczestniczenie w badaniach profilaktycznych etc.).

\section{EDUKACYJNY POTENCJAK SERIALU}

Seriale telewizyjne, ze względu na swoje szczególne właściwości, wykorzystywane były przez twórców programów edutainmentowych od samego początku. Te krótkie fabularyzowane opowieści przeżywają swój renesans od początku nowego stulecia. Szczególna popularność seriali związana jest m.in. ze znacznymi zmianami, jakie dokonały się w ich obrębie - obecnie mówi się o „erze post-soap” dla podkreślenia różnicy pomiędzy współczesną ofertą serialową a niegdysiejszymi operami mydlanymi lub telenowelami. Te ostatnie adresowane były przede wszystkim do kobiet w średnim wieku - gospodyń domowych. Współczesne produkcje oglądane są przez przedstawicieli różnych grup społecznych i wiekowych. Podczas gdy śledzenie wielowątkowych historii rodzinnych i miłosnych charakterystycznych dla soap-operas wiązało się z poczuciem wstydu, dziś wstydliwym 
jest brak znajomości fabuły najpopularniejszych z nich - oglądanie seriali jest obecnie po prostu modne - nadawane w prime time (czyli okresie największej oglądalności, zazwyczaj między 20.00 a 23.00) kolejne epizody serii przyciągają przed ekrany telewizorów rekordową widownię (najpopularniejsze z nich, jak np. „CSI: Crime Scene Investigation”, oglądane są przez ponad 63 milionów odbiorców z całego świata²). Jak zauważa Ewa Kaja (2014) „tematy poruszane w serialach typu post-soap nie mieszczą się często w ramach, jakie zwykliśmy kojarzyć z telewizyjną rozrywką” (s. 68). Dotykają bowiem przykładowo takich zagadnień, jak warunki pracy w korporacji, sytuacja osób odbywających bezpłatne staże, wykluczenie społecznie, zatrudnienie poniżej poziomu posiadanych kwalifikacji (Bałaga, 2014), choroby, uzależnienia, przemoc, prostytucja i dylematy etyczne związane z funkcjonowaniem w ponowoczesności (Godzic, 2004). Według Eweliny Twardoch (2014), seriale „wyznaczają nowatorską, hybrydyczną przestrzeń współczesnej kultury popularnej, opartą nie tylko na sławetnym enterteinmencie, ale i na subwersji, parodii, odniesieniach intermedialnych, praktykach konwergencyjnych” (s. 148).

Edukacyjność seriali przejawia się na wielu poziomach. Poruszane w nich problemy związane z ogólnym kontekstem społecznym i gospodarczym pomagają widzom przeanalizować własną sytuację i podjęte decyzje (Bogunia-Borowska, 2012). Serial pełni zatem dla niektórych formę „,poradnika życia” (Jakubowski, 2001), zwierciadła, w którym można „obejrzeć” własną rodzinę, pracę, doświadczenia podobnych sobie ludzi. Według Maryli Hopfinger (2010), seriale mają wartość poznawczą, integracyjną oraz wzorotwórczą. Ta ostatnia nie może być jednak traktowana zbyt dosłownie - nieco przesadnym wydaje się stwierdzenie, że „w zależności od tego, którego bohatera serialu obierze się jako tego dobrego, tak będą funkcjonowały stosunki międzyludzkie w świecie realnym” (Cikała, 2014, s. 54). Sposób oddziaływania przekazów telewizyjnych na sferę postaw i wartości bardzo celnie opisuje Godzic (2013): „medium nie sugeruje przejęcia konkretnych stylów życia - ale tak układa swoją pokawałkowaną narrację, że taki właśnie styl wyłania się samoistnie i powoduje łatwą identyfikację przez telewidza. Telewizja nie mówi na ogół, która z postaci ekranowych powinna wzbudzać sympatię, a która obrzydzenie u odbiorcy - ale każe zastanawiać się nad nimi” (s. 145). Współczesne teorie nie ujmują zresztą mediów jako wszechwładnego narzędzia wpływu kreującego jednorodną i bierną widownię. Widzowie są raczej

2 Źródło internetowe dostępne na stronie: http://tvbythenumbers.zap2it.com/2012/06/14/csi-crime-scene-investigation-is-the-most-watched-show-in-the-world-2/, [09.11.2015]. 
spostrzegani jako zindywidualizowani i rozproszeni, będący często jednocześnie twórcami tekstów medialnych i aktywnie z nimi polemizujący.

Mimo że seriale posiadają niewątpliwy potencjał edukacyjny i socjalizacyjny, należy je odróżnić od tych produkcji, których „edukacyjność” i „,socjalizacyjność” były głównymi motywami powstania (czyli programów edurozrywkowych) ${ }^{3}$. Według autorów książki „Entertainment-Education. A Communication Strategy for Social Change” rozbieżności pomiędzy obydwoma rodzajami widowisk dotyczą kilku wymiarów. Pierwszy z nich i chyba najbardziej oczywisty dotyczy faktu, że „zwykłe” seriale są tworzone w celu rozrywki i przynoszenia zysków, natomiast programy edutainmentowe wykorzystują rozrywkę po to, by „opakować” nią przekaz edukacyjny. Drugi poziom rozbieżności koncentruje się wokół moralnej niejednoznaczności versus koherencji. Seriale z wbudowanym przekazem edukacyjnym przyjmują określony sposób moralnej oceny zjawisk - np. jednoznacznie „potępiają” wczesne zawieranie małżeństw i „chwalą” stosowanie antykoncepcji. Wskazanie na preferowany przez twórców sposób postępowania wobec dylematu etycznego nie jest jednakże dokonywany wprost. Bezpośrednie zalecenie obrania konkretnych rozwiązań mogłoby się spotkać ze zdecydowanym oporem odbiorców, stąd też aplikowane są takie rozwiązania fabularne, które wystarczająco dobrze maskują moralne meritum założone przez autorów, przy zachowaniu jednoczesnej oczywistości odczytania dla widzów tego, „co się opłaca, a co nie” lub „co się powinno, a czego nie” (np. kilkunastoletnia dziewczynka wydana wcześnie za mąż zachodzi w ciążę i umiera podczas porodu, a małżeństwu stosującemu antykoncepcję polepszają się relacje i poprawia znacznie sytuacja materialna). Kolejna odmienność ma związek z realizmem, który według teoretyków edutainmentu jest znacznie większy w produkcjach zrealizowanych w celu zmiany społecznej. Seriale edukacyjne są zazwyczaj projektowane dla precyzyjnie określonej grupy odbiorców, stąd też dbałość, by fikcyjni bohaterowie byli maksymalnie podobni do rzeczywistych przedstawicieli danej warstwy społecznej, zawodowej lub wiekowej. Ostatnia z różnic zasadza się na sygnalizowanym już przeze mnie oparciu paradygmatu edurozrywki o liczne teorie, podczas gdy seriale telewizyjne opracowywane bez wyraźnej intencji edukacyjnej są w tym ujęciu ateoretyczne (Singhal, Rogers, 2011).

${ }^{3}$ W literaturze istnieją co prawda stanowiska (np. Moyer-Gusé, 2008), według których intencjonalność zawarcia treści edukacyjnych nie jest czynnikiem determinującym lub przesądzającym o edukacyjnym charakterze programu lub tekstu popkulturowego. Na potrzeby niniejszego opracowania będę ujmowała zjawisko education-entertainment zgodnie z podaną w tekście definicją, która opisuje strategię edurozrywki z perspektywy planowych i świadomych działań. 
Przedstawiona powyżej charakterystyka serialu w perspektywie edukacyjnej, zwłaszcza wyszczególnione różnice pomiędzy serialem komercyjnym a edukacyjnym, zostaną przeze mnie wykorzystane jako punkt odniesienia w części empirycznej niniejszego tekstu. Pozwolą bowiem przybliżyć odpowiedź na pytanie, czy „Głęboka woda” jest serialem edukacyjnym, czy pełni również, a być może nawet przede wszystkim, odmienne funkcje.

\section{GŁĘBOKA WODA JAKO SERIAL EDUKACYJNY (?)}

Serial, który stanowi przedmiot niniejszego opracowania, zrealizowany został ze środków Europejskiego Funduszu Społecznego (Program Operacyjny Kapitał Ludzki, poddziałanie 1.18 ,Tworzenie i rozwijanie standardów usług pomocy i integracji społecznej), na zlecenie Ministerstwa Pracy i Polityki Społecznej. Od samego początku reklamowany był przez urzędników MPiPS jako serial edukacyjny, który miał przybliżyć widzom profesję pracownika socjalnego oraz zadania Miejskich Ośrodków Pomocy Społecznej. Założenia i cele projektu, w ramach którego zrealizowany został pierwszy sezon serialu, to między innymi poprawa jakości pracy i usług świadczonych przez instytucje pomocy i integracji społecznej w zakresie przeciwdziałania wykluczeniu społecznemu oraz utworzenie nowych standardów pracy tychże instytucji. Pierwotny zamysł realizacji serialu powiązany był więc z popularyzacją efektów inicjatywy, która z kolei obejmuje tematyką przeciwdziałanie marginalizacji grup zagrożonych wykluczeniem lub wykluczonych, w szczególności osób bezdomnych. Druga seria miała na celu promowanie finansowanych przez Unię Europejską programów aktywizacji społeczno-zawodowej wobec grup zagrożonych marginalizacją bądź marginalizowanych.

Analiza, którą przedstawię poniżej, została wykonana na podstawie badań, w których udział wzięło 19 osób w wieku od 23 do 44 lat (12 kobiet i 7 mężczyzn). Dwoje badanych to osoby z wykształceniem średnim, reszta ukończyła studia na poziomie licencjackim, inżynierskim lub magisterskim. Badanymi były osoby, które nie znały wcześniej serialu lub obejrzały wcześniej np. tylko jeden odcinek. Dobór badanych został zrealizowany przy pomocy metody kuli śnieżnej, która należy do grona procedur wyłaniania grup o charakterze nieprobabilistycznym (Babbie, 2004). Pierwszymi osobami, które zaprosiłam do badania, były cztery osoby z mojego najbliższego otoczenia (studentka początkowych lat studiów w wieku ok. 20 lat oraz znajomi w wieku ok. 30 i ok. 40 lat). W zamierzeniu każda z tych osób miała „uzupełnić” próbę o osoby w zbliżonym wieku i o podobnym poziomie wykształcenia tak, by ostatecznie grupa badanych była zróżnicowana. 
Zależało mi na uzyskaniu opinii od osób będących w różnym wieku, mających przez to inne perspektywy i doświadczenia. Ostatecznie wśród badanych znalazło się dwoje studentów oraz siedemnastu dorosłych niebędących studentami. Mimo że grupa docelowa nie wydawała się szczególnie trudno dostępna, barierą okazała się konieczność obejrzenia serialu - część potencjalnych badanych rezygnowała z wzięcia udziału w projekcie po zapoznaniu się z opisem jego fabuły. Serial traktujący o pracownikach socjalnych wydawał im się nieinteresujący i nie chcieli przeznaczać swojego wolnego czasu na jego oglądanie.

Na materiał badawczy złożyło się 36 wypowiedzi pisemnych (dwie z nich odrzucono ze względu na ich częściowe wypełnienie) i 8 jakościowych wywiadów badawczych. Każdy z badanych proszony był o odniesienie się do trzech zagadnień, które dotyczyły pracy socjalnej i pracowników socjalnych, a następnie obejrzenie przynajmniej dwóch dowolnych odcinków serialu. W dalszej kolejności badani ponownie udzielali pisemnych wypowiedzi, skoncentrowanych wokół tych samych problemów. Badania zostały przeprowadzone z zachowaniem anonimowości ${ }^{4}$. Uzupełnieniem danych i pogłębieniem perspektywy było przeprowadzenie jakościowych wywiadów badawczych, które pozwoliły badanym na zaprezentowanie znaczeń i interpretacji, jakie nadali omawianemu tekstowi popkulturowemu. Dokonałam również jakościowej analizy treści serialu (25 odcinków składających się na obie serie). Badania, ze względu na liczbę i rodzaj próby, mają charakter niereprezentatywny.

Główny problem badawczy skoncentrowany jest wokół pytania o to, w jaki sposób (i czy w ogóle) serial „Głęboka woda” realizuje zaprojektowane zadania edukacyjne. Wyszczególniłam również następujące problemy szczegółowe: Jaki obraz pracowników socjalnych i pracy socjalnej mają osoby badane? Jak serial przyczynił się do zmiany postrzegania pracowników socjalnych i pracy socjalnej? Na czym polega ewentualna zmiana?

Według Marka Rymszy (2012) istota pracy socjalnej i profesja pracownika socjalnego są w Polsce wciąż słabo rozpoznawane i oparte na rozmytych, nieprecyzyjnych przekonaniach, które często sprowadzają się do ujmowania istoty pracy socjalnej jako „rozdawnictwa zasiłków”, a pracowników socjalnych jako „pani/pana od zasiłków”. Praca socjalna w „Ustawie z dnia 12 marca 2004 r. o pomocy społecznej” (2004) definiowana jest jako „działalność zawodowa

4 Abym mogła zidentyfikować i porównać wypowiedzi udzielone przed i po obejrzeniu serialu, poprosiłam badanych, by oznaczyli swoje arkusze pseudonimami. Wykorzystane zostały również one przeze mnie w niniejszym tekście, przy cytowanych fragmentach wypowiedzi. Autorów wywiadów natomiast oznaczyłam jako „kobietę” lub „mężczyznę”, podając dla zróżnicowania poszczególnych badanych ich wiek. 
mająca na celu pomoc osobom i rodzinom we wzmacnianiu lub odzyskiwaniu zdolności do funkcjonowania w społeczeństwie poprzez pełnienie odpowiednich ról społecznych oraz tworzenie warunków sprzyjających temu celowi” (artykuł 6 punkt 12). Z kolei według Międzynarodowej Federacji Pracowników Socjalnych „praca socjalna promuje zmianę społeczną, rozwiązywanie problemów w relacjach międzyludzkich i wzmocnienie (empowerment) oraz wyzwolenie ludzi w celu poprawy (zwiększenia) ich dobrostanu” (Trawkowska, 2010, s. 186). Wśród wypowiedzi respondentów odnośnie do tego, czym jest w ich przekonaniu praca socjalna, znalazły się takie, które można określić jako bardzo ogólne, lakoniczne, będące być może wyrazem szczątkowej wiedzy badanych na dany temat, jak np.:

Pomoc innym. (Fusica)

Praca wykonywana na rzecz społeczeństwa. (Ray Donovan)

Dq̨żenie do pomocy ludziom, borykajq̨cym się z problemami społecznymi. (Greenpeace)

Jak i wykazujące rozumienie jej założeń:

Praca socjalna według mnie ukierunkowana jest na pomoc osobom, które przechodzq trudności w obecnym stanie osobowym. Nie potrafiq odnaleźć $w$ sobie wystarczajacych motywacji, do poprawy swojej trudnej sytuacji materialnej i psychicznej. Celem pracy socjalnej jest pomoc, w adaptacji społeczności wykluczonych, i ułatwienie osobom wykluczonym powrotu do społeczeństwa. (sensei)

Pomoc w wyjściu z problemu i ponownemu pełnieniu pozytywnych ról społecznych. Wsparcie. Praca socjalna zasadza się na trzech filarach: ratunku, opiece i kompensacji społecznej. Jest reakcjq na nieprawidłowości występujq̨ce w rodzinie, na odejścia od przyjętej normy oraz prowadzi działania pozwalajq̨ce powrócić na dobrq ścieżkę. (Szogun)

Większość badanych definiuje pracę socjalną poprzez wskazanie grup, do których jest kierowana pomoc społeczna. Właściwie identyfikują oni osoby, które zgodnie z Ustawą mogą być objęte opieką państwa, wskazując na jednostki i grupy borykające się z trudnościami finansowymi, nałogami, chore, doświadczone przez zdarzenia losowe. W opracowanych przeze mnie pytaniach znalazło się również takie, które dotyczyło zakresu obowiązków pracowników socjalnych. Odpowiedzi udzielone przez respondentów można podzielić na trzy 
grupy: zawężone, ujmujące problem, np. w jednym zdaniu szerokie - przypisujące pracownikom socjalnym dodatkowe role i obowiązki, oraz wskazujące na zbliżony do rzeczywistego zakres powinności omawianej grupy zawodowej. Punktem wyjścia dla wyróżnienia powyższych kategorii był wykaz obowiązków i zadań pracowników socjalnych określonych przez cytowaną już przeze mnie ustawę (artykuł 119, punkt 1). Przekonania, które umieściłam w pierwszym zestawie, prezentują się następująco:

Reagowanie na wołanie o pomoc. (M)

Nie wiem, na czym polegaja, ale powinny wg mnie polegać na zarzqdzaniu zasobami w odniesieniu do grup społecznych, które ma pod opiekq, utrzymywaniu kontaktu z osobami, które ma pod opiekq. (Ray Donovan)

Według Michała Szyszki (2012) zadania Ośrodków Pomocy Społecznej funkcjonują w obszarze „społecznej niewiedzy” - mieszkańcy miast, w których są usytuowane, zazwyczaj mają świadomość ich obecności, nie wiedzą natomiast jakie są ich zadania, słabo rozpoznają grupy beneficjentów pomocy i problemy, jakie są ich udziałem. Taki stan rzeczy może z kolei prowadzić do powstawania uprzedzeń i negatywnych postaw wobec instytucji pomocowych.

Kolejna kategoria wypowiedzi zawiera opinie, które przypisują pracownikom socjalnym szereg ponadprogramowych funkcji i zobowiązań:

Na pracy w poradniach rodzinnych, zawodowych, pełnieniu funkcji pedagoga, psychologa, wsparcia psychicznego, budowania własnej wartości oraz na konkretnych działaniach, np. na szukaniu pracy osobom, które jej potrzebujq, resocjalizacji trudnej młodzieży, na wsparciu osób uzależnionych od alkoholu i narkotyków, na działaniach, które doprowadzq do umieszczenia ich w ośrodkach odwykowych, na szukaniu rodzin zastępczych (nie jestem pewna czy też na pomocy w adopcji dziecka), na pracy, która niesie pomoc w trudnych sytuacjach, w których ludzie przestali sobie radzić sami i sq tego świadomi lub nie dopuszczaja do siebie podobnych myśli. (tiril)

Znalazły się tutaj również takie stwierdzenia, które wyraźnie idealizują analizowaną rolę, nadają jej „romantycznych” i wzniosłych cech:

Osoba, która jest pracownikiem socjalnym powinna doglqdać rodziny lub osoby co do których/której została przydzielona. Doglq̨danie powinno polegać 
na całkowitym zaangażowaniu pracownika w rozwiq̨zanie kłopotów jak i bycie wsparciem psychicznym nie tylko przy okazji kolejnych „co miesięcznych” wizyt kontrolnych. Pracownik socjalny powinien posiadać w swego rodzaju powołanie do pracy. Pracownik socjalny powinien być wsparciem dla podopiecznych aby mogli zobaczyć że można żyć inaczej niż to co pokazuje im dom bq̨dź najbliższe środowisko. (PATI)

Zgodnie z zacytowaną powyżej opinią, pracownicy socjalni jawią się jako grupa zawodowa o szczególnych predyspozycjach do wykonywania swojej pracy (powołanie). Respondentka oczekuje, że będą stanowili wzór, model do naśladowania dla swoich podopiecznych, będąc przy tym bez reszty skupionym na próbie pomocy i znalezieniu jak najlepszego rozwiązania. Magdalena Rek-Woźniak (2012) zwraca uwagę, że „misyjność” i głębokie angażowanie się są częściej przypisywane organizacjom pozarządowym zajmującym się pomocą społeczną aniżeli przedstawicielom instytucjonalnych form wsparcia. Autorka podkreśla także, że warstwa językowa zapisów ustawowych, które określają, czym powinien zajmować się pracownik socjalny, kreuje obraz lokalnego lidera, animatora społeczności oraz „'specjalisty od pomagania’, efektywnego pracownika administracji, który - pełniąc funkcję pośrednika między państwem a obywatelami - ma za zadanie skutecznie modelować zachowania zgodne ze standardami wolnorynkowego ładu” (s. 120).

Ostatnia z wydzielonych grup odpowiedzi zawiera takie wyobrażenia spektrum obowiązków pracowników socjalnych, które pokrywają się z rzeczywistym wymiarem ich pracy:

Pracownik socjalny to dla mnie urzędnik państwowy pomagający ludziom $w$ terenie $i$ w siedzibie organu pomocy społecznej. Do innych obowiqzzów może należeć ocenianie zasadności pomocy społecznej albo skala takiej pomocy. Robi wizje lokalne, rozmawia z ludźmi, poznaje ich sytuacje i problemy, analizuje dokumenty, szuka rozwiqzań dla swoich klientów, prowadzi ich sprawy. Powinien odnajdować, wychodzić do potrzebujących (akcje informacyjne, reklamowe). Pomoc starszym i samotnym $w$ domu, rodzinom $w$ trudnych sytuacjach bytowych, organizuje woluntariuszy. (Pan Balonik)

Moim zdaniem pracownik socjalny przeprowadza wywiady środowiskowe i planuje pomoc dla osób potrzebujących. Pomaga rodzinom uzyskać świadczenia z pomocy społecznej, stosujq̨c się do przepisów prawnych. Wspiera zagubionych ludzi i okazuje im zrozumienie. (Misia) 
Co ciekawe, wśród wypowiedzi nie znalazła się ani jedna, która zawierałaby negatywną ocenę pracowników socjalnych lub samej instytucji pomocy społecznej. Jest to o tyle zaskakujące, że według badań przeprowadzonych przez Magdalenę Dudkiewicz (2012) prawie 80\% pracowników socjalnych jest przekonanych, że opinia publiczna spostrzega ich działanie jako „pomaganie darmozjadom”, a niemal 50\% sądzi, że pomoc społeczna traktowana jest jako „marnowanie publicznych pieniędzy” (s. 126). Pejoratywny odbiór tej grupy zawodowej wśród społeczeństwa jest również sygnalizowany w opracowaniach poświęconych wizerunkowi pracowników socjalnych (np. Szyszka 2012; Rymsza 2012). Tendencje te nie znajdują odzwierciedlenia w badanej przeze mnie grupie. Ogólny portret pracownika socjalnego, jaki wyłania się po przeanalizowaniu uzyskanych informacji, jest nieco wyidealizowany - łączący cechy urzędnika i psychologa - doradcy. Praca socjalna jest natomiast spostrzegana przede wszystkim jako wsparcie dla jednostek i grup borykających się z ubóstwem, nieradzących sobie, mających trudności w przystosowaniu się, widziana jako próba ponownego włączenia ich do społeczeństwa.

Badani formułowali spostrzeżenia dotyczące pracowników socjalnych i ich pracy ponownie $e^{5}$ po obejrzeniu przynajmniej dwóch ${ }^{6}$ odcinków serialu. Zabieg ten powodowany był chęcią odkrycia, jak zmieniają się przekonania respondentów odnośnie do wskazanych kwestii i czy w ogóle ulegają przeobrażeniom? Jak już wspominałam, „Głęboka woda” przy okazji promocji serialu (w 2011 r.), była prezentowana jako serial edukacyjny - Jarosław Duda, ówczesny sekretarz stanu, w liście do pracowników socjalnych wyraził oczekiwanie, że „widzowie po obejrzeniu serialu zrozumieją charakter tego zawodu, możliwości i ograniczenia skutecznego działania”?.

W powtórnych konstatacjach zauważyć można dwie główne tendencje: pierwsza z nich to brak reorientacji u badanych w zakresie przekonań/wiedzy odnośnie do pracy socjalnej i pracowników socjalnych, który wyrażał się w udzielaniu bardzo zbliżonych lub dokładnie takich samych odpowiedzi (w porównaniu do

${ }^{5}$ Czas pomiędzy sformułowaniem pierwszej i drugiej opinii wynosił od tygodnia do dwóch miesięcy. Najwięcej powtórnych wypowiedzi (12 spośród 19) uzyskałam po trzech tygodniach od uzupełnienia pierwszego arkusza odpowiedzi.

${ }^{6}$ Część respondentów sygnalizowała, że obejrzała znacznie więcej odcinków, np. pełne dwa sezony.

7 List Sekretarza Stanu Jarosława Dudy do Pracowników Socjalnych, dotyczący wyświetlenia w Telewizji Polskiej serialu „Głęboka Woda”, który ma na celu ukazanie społeczeństwu misji zawodu pracownika socjalnego, dostępny na stronie: http://www.mpips.gov.pl/gfx/mpips/userfiles/ File/Aktualnosci/Pomoc\%20spoleczna/Gleboka_woda_03.06.11.pdf, [16.11.2015]. 
pierwszej, wraz z informacją, że po obejrzeniu serialu nic nie uległo zmianie trzy opinie). Jeden z badanych zamieścił również obszerniejsze „wytłumaczenie” powtórzenia swoich poglądów:

Moje wyobrażenie się nie zmieniło, w sumie było takie jak ten film pokazuje. Więc pozostawiam swojq ankietę niezmienionq. Film wydaje mi się i tak słabszy, aniżeli niesie to samo życie. W pierwszym odcinku, po tym jak się przedstawia, „,nowy dyrektor” mówi jakie cechy ma mieć dobry pracownik socjalny. W definicji jego - nic dodać, nic ujq̨ć, samo sedno - ktoś kto adaptował te słowa do scenariusza musiał mieć duże doświadczenie. (EdwardĄcki)

Przywołana przez respondenta charakterystyka pracownika socjalnego dokonana przez serialowego dyrektora MOPS-u Wiktora Okulickiego (w tej roli Marcin Dorociński) brzmi następująco: „Zastanawiałem się też, jakie cechy powinien mieć pracownik socjalny. Myślę, że powinien być wrażliwy, ale niekierujący się tylko uczuciami, współczujący, ale kompetentny, operatywny, nieustępliwy, energiczny i bardzo, bardzo, bardzo cierpliwy. Musi znać przepisy na tyle dobrze, aby móc je zgrabnie omijać. Dobrze, jeśli zna kilka chwytów Kung-Fu, to się może przydać. Słowem, takie połączenie Spidermana z Matką Teresą”.

Wątek lekceważącego traktowania przepisów prawnych znalazł także swoje odzwierciedlenie w wypowiedziach badanych. Pytani po raz drugi, czym jest praca socjalna i co należy do obowiązków pracowników socjalnych, umieszczali m.in. następujące sformułowania:

Wykorzystywaniu luk prawnych, umożliwiających obejście przepisów podczas działania. Wychodzenie poza swoje kompetencje oraz naginanie prawa. (Szogun)

Natomiast wśród pożądanych cech pracownika socjalnego znalazły się takie oto wskazania:

Kompetentny, „ludzki”, umiejący szybko reagować na danq sytuację, miły, wrażliwy, stanowczy, odważny... znający przepisy po to aby je ładnie omijać. (Fusica)

Powinien doskonale znać przepisy prawa, wg których działa i postępować zgodnie z nimi, ale dostosowując je twórczo do poszczególnych sytuacji. (Maria Magdalena) 
Drugi kierunek zmian, jaki wyłania się z formułowanych opinii, to wyraźne przesunięcie akcentów w charakteryzowaniu pracowników socjalnych z „empatii” i „zrozumienia” na „twardość” i „odporność na stres”. Wśród stanowisk badanych obecne były również takie określenia, jak „silny”, „umiejący radzić sobie w sytuacjach nagłej presji lub kryzysu”. Pojawiła się również opinia, zgodnie z którą:

Pracownik socjalny powinien walczyć o swoich podopiecznych. (Misia).

Podobne wypowiedzi pojawiły się również w przeprowadzonych wywiadach:

No można się nauczyć, że jest to bardzo ciężka praca. Że to jest ciężka praca, naprawdę kawał roboty takiej bardzo niewdzięcznej. Rzadko można zobaczyć efekty, a często można dostać w łeb. (Kobieta, 37 lat)

Trudne warunki, zabiegani ludzie. Co chwilę coś się dzieje, pod telefonem. Majq trudne życie. (Mężczyzna, 44 lata)

W obliczu analizy treści serialu przekonania utrzymane w tym tonie nie są zaskakujące. W pierwszym sezonie „Głębokiej wody” profesja pracownika socjalnego została określona m.in. jako wyczerpująca, nisko płatna, wypalająca i dobra dla masochistów. Charakterystyka warunków pracy zarysowana przez dyrektora Okulickiego to „młyn, kołowrót, strasznie dużo roboty. A jak się zrobi trochę swobodniej, to się zdarzy jakiś szalony święty albo kobieta bez zęba”. Respondenci definiowali również pracę socjalną jako polegającą

na niesieniu wszelkiej pomocy tym, którzy znaleźli się w ciężkiej sytuacji życiowej. (tiril)

Według badanych, pracownik socjalny

powinien liczyć się z nieregularnymi godzinami pracy i interwencjq w różnych porach dnia i nocy (tiril)

oraz posiadać umiejętność poświęcenia własnego czasu w sytuacjach kryzysu. (Lubie Placki) 
Ten kierunek narracji jest również zgodny z serialową wersją pracownika socjalnego i pracy socjalnej. Bohaterowie „Głębokiej wody” pracują bowiem niemal bez przerwy. Na rzecz rozwiązywania problemów swoich klientów przeznaczają prywatny czas oraz środki materialne (jedna z pracownic - Alina - z własnych pieniędzy kupuje nastoletniej podopiecznej płytę kompaktową i telefon komórkowy. W innym odcinku jedzie do Włoch w ramach swojego urlopu by odszukać ojca dwojga nieletnich, znajdujących się pod opieką Ośrodka).

\section{ZAKOŃCZENIE}

We fragmencie poświęconym różnicom pomiędzy serialem komercyjnym a edukacyjnym, za Singhalem i Rogersem wymieniłam kilka kluczowych cech dla drugiego typu audycji: moralną spójność, bliską realizmowi fabułę i oparcie na teorii. Przeprowadzona powyżej analiza wskazuje, że „Głębokiej wodzie” daleko jest do uzyskania statusu programu edukacyjnego. Serial nie jest koherentny pod względem etycznym (co więcej, w niektórych momentach prezentuje działania odbiegające od zakładanych powinności - bohaterowie działają niezgodnie z prawem, łamią także normy moralne - jedna z pracownic socjalnych nawiązuje bowiem relację intymną z klientem), nie odzwierciedla również rzeczywistości ${ }^{8}$. Często podnoszonym argumentem, odpierającym zarzut o braku realizmu serialu, jest ten, który przytacza Dudkiewicz: „pytanie tylko, czy w ogóle medialne może być wypełnianie dokumentów, realizowanie procedur i praca urzędnicza. Myślę, że należy spróbować ustalić, jak dalece prawdziwe jest to, co pokazują seriale o lekarzach, policjantach czy prawnikach. Sądzę, że takie podkoloryzowanie rzeczywistości po to, żeby ją uatrakcyjnić medialnie - jeśli chce się przekonać społeczeństwo do tego, że robi się rzeczy trudne, ale potrzebne - jest nieuniknione” (s. 139). Porównywanie komercyjnych produkcji do serialu, którego koncepcja została opracowana przez urzędników MPiPS, a realizacja sfinansowana z funduszy unijnych, jest w mojej opinii bezzasadne.

Ponad czterdzieści lat doświadczeń badaczy i praktyków realizujących programy edurozrywkowe pokazuje, że ,gatunek” ten powinien być projektowany z dużą precyzją i ostrożnością. Literatura obfituje bowiem w przykłady efektów programów edutainmentowych, które były dokładnie odwrotne od zamierzonych,

8 Opinie pracowników socjalnych dotyczące relacji serialu i ich rzeczywistej pracy zostały przeze mnie zasygnalizowane w artykule (2015) pt. Serial jako narzędzie aktywizacji społecznozawodowej? Analiza „Głębokiej wody”. Studia Edukacyjne, 35. 
a tym samym - bardziej szkodziły, niż pomagały (tzw. efekt Archiego Bunkera). Z pewną dozą ostrożności mogę sformułować wniosek, że podobny skutek odniósł analizowany przeze mnie serial. Badana próba nie miała oczywiście charakteru reprezentatywnego, jednakże jakość przekonań, które zostały wyartykułowane przez respondentów po zapoznaniu się z serialem, jest co najmniej zastanawiająca. Ograniczenie widowiskowej oprawy serialu na rzecz jego rzetelności oraz szerokie wykorzystanie wiedzy o paradygmacie education-entertainment mogłyby przyczynić się do zrobienia z „Głębokiej wody” serialu edukacyjnego. Obecnie można mu przypisać ,jedynie” rolę narzędzia PR-owego. Nie wiadomo natomiast dokładnie, kogo PR miałby dotyczyć - bynajmniej nie pracowników socjalnych i realizowanych przez nich na co dzień zadań, których faktyczny wymiar okazał się dla reżyserów i scenarzystów serialu niewystarczająco „filmowy”. Stwierdzenie, że „rzeczywistość nie jest dobrą telewizją” (Jastrzębski, 2011, s. 89) wydaje się w kontekście analizowanego problemu wyjątkowo trafną i gorzką konstatacją. Gorzką, bo niesie ze sobą konsekwencje dla grupy zawodowej, która nie może liczyć na nadmiar pozytywnego wizerunku w mediach. Nie otrzymała go również niestety za pośrednictwem serialu, który miał odwrócić fatalną passę publicznych nagonek, a stał się wyłącznie sensacyjną, przepełnioną problemami fikcją.

\section{Literatura:}

Babbie, E. (2004). Badana społeczne w praktyce. Warszawa: Wydawnictwo Naukowe PWN.

Bałaga, M. (2014). Nowy wspaniały świat i stare problemy. Ekonomia w serialach nowej generacji. W: M. Małgorzata, J. Bucknall-Hołyńska (red.), Władcy torrentów. Wokół angażującego modelu telewizji (s. 159-168). Gdańsk: Wydawnictwo Uniwersytetu Gdańskiego.

Bogunia-Borowska, M. (2012). Fenomen telewizji. Interpretacje socjologiczne i kulturowe. Kraków: Wydawnictwo Uniwersytety Jagiellońskiego.

Cikała, K. (2014). Życie w rytmie serialu. Rola serialu w kształtowaniu świata wartości widzów. W: A. Krawczyk-Łaskarzewska, A. Naruszewicz-Duchlińska, P. Przytuła (red.), Seriale w kontekście kulturowym. Gatunki, konwergencja, recepcja (s. 47-58). Olsztyn: Instytut Filologii Polskiej Uniwersytetu Warmińsko-Mazurskiego w Olsztynie.

Duda, J. (2011). List Sekretarza Stanu Jarosława Dudy do Pracowników Socjalnych dotyczący wyświetlenia w Telewizji Polskiej serialu „Głęboka Woda”, który ma na celu ukazanie społeczeństwu misji zawodu pracownika socjalnego. Pobrane z: http:// www.mpips.gov.pl/gfx/mpips/userfiles/File/Aktualnosci/Pomoc\%20spoleczna/Gleboka_woda_03.06.11.pdf.

Dudkiewiecz, M. (2012). Jak nas widzą, tak nas piszą - wizerunek publiczny pracowników 
socjalnych. W: M. Rymsza (red.), Pracownicy socjalni i praca socjalna w Polsce. Między służbą społeczną a urzędem (s. 121-139). Warszawa: Instytut Spraw Publicznych. Godzic, W. (2004). Telewizja i jej gatunki: po „Wielkim Bracie”. Kraków: Universitas. Godzic, W. (2013). Kuba i inni. Twarze i maski popkultury. Warszawa: Wydawnictwo Akademickie SEDNO.

Hopfinger, M. (2010). Literatura i media po 1989 roku. Warszawa: Oficyna Naukowa. Jakubowski, W. (2001). Telewizja i edukacja, czyli czego możemy nauczyć się z serialu. W: J. Kargul (red.), Dyskursy młodych andragogów, t. 2 (s. 55-65). Zielona Góra: WSP im. Tadeusza Kotarbińskiego.

Jakubowski, W. (2014). Media i kultura popularna jako obszar studiów nad edukacją. Studia Edukacyjne, 30, s. 91-107.

Jastrzębski, J. (2011). Ideologia i komunikacja. O edukacji, pedagogice i mediach. Wrocław: Wydawnictwo Uniwersytetu Wrocławskiego.

Kaja, E. (2014). Amerykańskie serialu typu „post soap-opera” - nowa generacja seriali telewizyjnych, lecz nie tylko w telewizji. Kultura i Edukacja, 2 (102), s. 64-82.

Kubicka, D. (2007). Społeczno-poznawcza teoria komunikacji masowej Alberta Bandury. W: D. Kubicka, A. Kołodziejczyk (red.), Psychologia wpływu mediów. Wybrane teorie, metody, badania (s. 51-62). Kraków: Oficyna Wydawnicza „Impuls”.

Moyer-Gusé, E. (2008). Toward a Theory of Entertainment Persuasion: Exploring the Persuasive Effects of Entertainment-Education Messages. Communication Theory, 18, s. 407-425, DOI:10.1111/j.1468-2885.2008.00328.x.

Ptaszek, G. (2013). Psychologia mediów - historia, obszar badań i perspektywy. W: A. Ogonowska Agnieszka, G. Ptaszek (red.), Współczesna psychologia mediów. Nowe problemy i perspektywy badawcze, (s. 13-33). Kraków: Oficyna Wydawnicza „Impuls”. Rek-Woźniak, M. (2012). Dobroczyńcy, biurokraci, kozły ofiarne? O społecznym konstruowaniu wizerunku pracowników socjalnych w Polsce. Kultura i Społeczeństwo, 1 (55), s. 101-125, DOI: 10.2478/v10276-012-0005-5.

Rymsza M. (2012). Pracownicy socjalni i praca socjalna w Polsce. W: M. Rymsza (red.), Pracownicy socjalni i praca socjalna w Polsce. Między służbą społeczną a urzędem (s. 11-33). Warszawa: Instytut Spraw Publicznych.

Singhal, A. (2013). Introduction: Fairy tales to digital games: the rising tide of entertainment-education. Critical Arts: South-North Cultural and Media Studies, 1 (27), s. 1-8. Singhal, A., Rogers, E.M. (2011). Entertainment-Education: A Communication Strategy for Social Change. New York and London: Routledge Taylor \& Francis Group.

Sood, S., Menard, T., Witte, K. (2010). The Theory Behind Entertainment-Education. W: A. Singhal., M.J. Cody, E.M. Rogers, M. Sabido (red.), Entertainment-Education and Social Change. History, Research, and Practice (s. 117-149). New York and London: Routledge Taylor \& Francis Group.

Szyszka, M. (2012). Kształtowanie wizerunku instytucji pomocy społecznej w mediach. Warszawa: Instytut Rozwoju Służb Społecznych. Pobrane z: http://wpis.irss.pl/wp-content/uploads/2015/03/Ksztaltowanie-wizerunku-instytucji-pomocy-spolecznejw-mediach.pdf.

Trawkowska, D. (2010). Bariery rozwoju pracy socjalnej w pomocy społecznej w perspek- 
tywie systemowej. Przykład pracy socjalnej z rodziną. Roczniki Socjologii Rodziny, XX, s. 185-208.

Twardoch, E. (2014). Śmierć i dziewczyna. O nieoczywistej metafizyce zbrodni w serialach inspirowanych Miasteczkiem Twin Peaks. W: M. Małgorzata, J. Bucknall-Hołyńska (red.), Władcy torrentów. Wokół angażującego modelu telewizji (s. 147-158). Gdańsk: Wydawnictwo Uniwersytetu Gdańskiego.

Ustawa z dnia 12 marca 2004 o pomocy społecznej. Pobrane z: http://isap.sejm.gov.pl/ DetailsServlet?id=WDU20040640593. 